\title{
Estate Planning: A Complex Process of Critical Importance to Ranches
}

\section{By Wayne A. Hayenga and Conner Wilson}

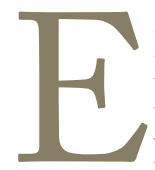

state planning is much more than deciding what kind of will to write or calculating potential estate taxes. Estate planning is an ongoing process. It can affect how and when you buy property, how you structure land and bank account titles, and how you organize and structure your business. It involves consideration of estate taxes, gift taxes, and income taxes during your lifetime and after your death. Estate planning also involves property management during your lifetime, particularly if you become disabled. Providing financial assistance for family members and preparing for retirement are also estate-planning considerations.

Most importantly, estate planning revolves around the wishes of those making the plan, both during one's lifetime and after one's death. The usual goals are the following: 1) to achieve the desired usage of assets after one's death, 2) to minimize transfer taxes, 3) to provide for the management of property after death for loved ones, and lastly, 4) to prevent family conflicts after one's death.

\section{Estate-Planning Process}

Estate planning is a process. Step one is to determine your objectives, and this is often the hardest part of the process. Step two is to analyze the cheapest, easiest, and most beneficial way to transfer property to designated beneficiaries. Step three is to estimate taxes and other transfer costs, and to revise goals if significant cost savings can be obtained. Step four is to evaluate the effect of transfer plans on the finances of your heirs.

\section{Identifying the Goals}

The most difficult task in estate planning is to identify the goals. Goals are individual concerns. It is not uncommon for husbands and wives to differ on many aspects when discussing an estate plan. Potential heirs usually have differences of opinion on how an estate should be planned. Goals are often difficult to communicate, not just to an estateplanning advisor, but for property owners to describe to themselves. Goals change over a lifetime, and they change with the amount of property available to leave to loved ones. They also change with the proximity and interest of beneficiaries in the business. Most bothersome to many is when goals conflict, and every goal cannot be attained. Generally, parents want to disperse their assets equally among all their children. This may be difficult if the primary asset is a ranching operation that will not provide employment for all children or for children not interested in ranching or in owning a part of the ranch.

There are a number of specific questions a family must be prepared to answer when constructing an estate plan (see Table 1). The will writer needs to be confident that the estate planner is competent to handle this very important task for the family. Questioning the estate planner about his/her ability, skill, interest, and knowledge of the ranching business is appropriate (see Table 2). It is advisable that family members should answer these questions individually and discuss them together. The process of answering these questions can build consensus and focus for the goals and objectives of the estate plan.

\section{How to Pass Property}

There are four ways to pass property at or after death. They include the following: 1) by contract, 2) by operation of law, 3 ) by trust, and 4) by the probate process. Selecting the way in which one wants to pass property depends on balancing the easiest, cheapest, and most beneficial ways to remember our loved ones.

Life insurance, retirement funds, and annuities pass by contract. The property owner enters into an agreement with the company, so that upon his death the company will pay to a beneficiary either a lump sum or a series of payments. Property can also pass by operation of certain laws. For example, in most states, taking title to land or a bank account as "joint tenants with right of survivorship" is a simple process, but it has its hazards. When holding a title like this, upon the death of one party, all the property becomes property of the surviving party. With this in mind, provisions should be made in the event that both joint tenants perished unexpectedly. The third way to pass property is 


\section{Table 1. Questions to be asked by the professional advisor to ranch families interested in estate plan-}

ning

1. How do you want to leave the property for the loved ones?

2. Should it be left outright so they can do what they want to with the property?

3. Should the property be restrained to meet a particular purpose you have in mind?

4. Are there any loved ones who are not "financially wise" who may need help in managing their property?

5. Have any of the beneficiaries had past financial trouble so you may not want to give them ownership of property?

6. Do you want to make sure that your property will not go to your spouse's next spouse or a former son-in-law?

7. Is it a goal to keep your family ranch in the family to provide employment for some of your heirs?

8. If a gift plan is undertaken, what are the tax costs and benefits to your family?

9. Are your potential heirs reasonably compatible or are there potential conflicts?

10. What can be done to avoid expected conflicts?

\section{Table 2. Questions that an individual or family should ask when choosing an estate planner}

1. Do they ask enough questions to determine the needs and feelings about the management and disposition of your property?

2. Are they a member in the appropriate professional societies and meetings to keep up to date?

3. Do they suggest ideas on how to do things differently in your business to save taxes or make operation of the estate easier?

4. Are they interested in working up a plan to meet your needs and desires?

5. Are they busy? (Usually the busier the better.)

6. When asked a question on a topic that they do not know the answer, are they willing to find out for you?

7. Would you feel comfortable discussing very personal values and family situations with them?

8. Do they understand the economics of your business?

9. Do they explain various tax and administrative options available to you so you can make informed decisions?

10. Are they willing to become involved with other appropriate professionals such as accountants, trust officers, or life insurance agents to implement your plan?

11. Do they have a basic understanding of your assets and understand the types of management they need?

12. Do they have the compassion your family will need in times of stress?

13. Do you feel they can help mediate any family differences rather than cause fights among your loved ones?

14. Do they offer advice to help you to select between options, but refrain from making decisions for you?

with a trust. A trust can be a powerful estate planning tool. Property can pass either at a person's death or many years after death if a trust is used. A trust is a legal entity whereby one person who has property, called the settlor, transfers legal, but not equitable, title to a trustee to hold it and to transfer it to a beneficiary at a particular time or for a particular purpose. In a trust there may be more than one settlor, one trustee, and one beneficiary. When the property is in a trust, a settlor's death may not alter the provisions of the trust, but the trustee can follow the settlor's instructions to pass the property to the appropriate beneficiaries as per the terms of the trust instrument. Questions about who can be a trustee often come up. Any person that has capacity to take legal title to property or a corporation that has been granted trust powers by the state (usually a bank) can serve as a trustee. In fact, a settlor can be his or her own trustee while alive. When the trustee dies, a properly drafted trust instrument will have a successor trustee named who can continue the provisions of the trust. Because a trust separates legal title from beneficial enjoyment of property, it can be used for a wide variety of purposes. Another benefit of a trust is that, after a trust becomes irrevocable, it is a separate taxpayer. Any income the trust pays to a beneficiary will be taxed to the beneficiary, but income the trust retains will be taxed to the trust. If the possible beneficiaries do not need the income the trust earns, and the trust is structured to pay income to any of several beneficiaries or to retain the earnings and add them to the trust principal, substantial tax savings can result. The final way to pass property is through the probate process. If property does not pass any other way, upon death the probate process takes over. If a person has a will, the will controls the disposition of the estate. If a person does not have a will, state law will control the disposition of the person's estate. One thing to remember is that all property, no matter how it passes to the heirs, will be subject to estate tax if the decedent had "dominion and control” over the property at death. See Table 3 for recommended steps to follow upon death.

\section{The Tax Picture}

The transferring of property to loved ones may be subject to estate or gift taxes, but a properly drafted estate plan may 


\section{Table 3. Recommended steps to follow after death for estate administration}

1. Make funeral arrangements

2. Contact planning attorney to make an appointment to review and discuss will, trusts, and other planning that has been implemented

3. Locate and study will, and any codicils to the will

4. Meet with family and family lawyer

5. Implement estate protection

- Collect and safeguard valuables

- Insure and protect property as necessary

- Obtain details of business interests

- Gather and preserve decedent's financial records and papers

6. Initiate probate

- Arrange to have the will probated

- Determine whether out-of-state administration will be required

- Obtain formal appointment of personal representative

7. Assemble and inventory assets

- Divide community property liquid assets

- Transfer decedent's interest in bank accounts and securities into the name of estate

- Collect money owed or payable to the estate

- File claims for life insurance

- Locate and take control of all other assets

- Determine precise legal title to all assets, both real and personal

- Obtain copies of all deeds, bills of sale, account signature cards, stock or bond certificates, partnership agreements, other business agreements, any buy/sell agreements, trusts in which the decedent had an interest, documents reflecting any powers of appointment possessed by the decedent, and any other evidence of ownership in property

- Compile detailed list of estate assets, including those not passing by will

8. Appraise and value estate

- Establish market value of all assets on date of death

- If needed for tax purposes, revalue assets six months after death

- Check availability of reduced valuation for ranch or business real estate

9. Manage estate

- Analyze cash needs and decide how to raise the money

- Collect dividends, interest, rents and other estate income

- Look after real estate and supervise business interests as required

- Maintain detailed records of all transactions, income, and expenses

10. Handle claims against the estate

- Notify estate creditors

- Pay final medical bills and apply for medical reimbursement

- Pay claims

- Question doubtful claims and defend estate against those not justified

11. Deal with taxes

- File final income tax return for decedent, fiduciary income tax returns for estate, and pay taxes due

- Pay property taxes and local taxes as they become due

- Determine need for post-mortem tax planning, including marital deduction election for any terminable interests passing to spouse and disclaimers

- File federal estate tax return and state returns as required

- Prepare for tax audit throughout estate administration by keeping detailed and accurate records of transactions, payment of claims, and valuation methods

- Defend estate against improper assessments of tax

12. Maintain good accounting procedures

- Maintain detailed and accurate books and records

- Submit progress reports to beneficiaries as settlement of estate progresses

- Prepare a formal final accounting and provide to all those who are entitled

13. Distribute estate

- Pay cash legacies and other bequests as directed in the will

- Transfer funds to trusts as called for in will

- Distribute all remaining assets 
save income taxes for the surviving family members. Under the current federal tax rules each person can give a lifetime exclusion amount of $\$ 3.5$ million away tax free in 2009. Of this exempt amount, $\$ 1.0$ million may be applied against gift taxes for lifetime transfers, and whatever remains will be available to the person's estate. In addition to the lifetime exclusion amount, the unlimited marital deduction makes all transfers to a spouse tax free for both lifetime and death time transfers. Also, there is an annual exclusion from the gift tax of $\$ 13,000$ per donee per year for qualifying gifts. These three generous exemptions seem to make transfer tax planning easy, but there are other hidden factors that the family should be aware of. After the tax free amounts are passed, the tax rates for gifts are $35 \%$ and $45 \%$ for estate transfers. If a person's estate looks as though some estate tax will be due at death, making gifts of under $\$ 13,000$ per person per year is often considered. As long as the $\$ 13,000$ gift is complete in that the donee has complete control of the property, the gift is tax free. But, if a person does not think this estate will be subject to transfer taxes, caution should be held in making gifts of non-cash assets. The reason: income taxes of the donee. With inherited property, the recipient's income tax basis is the date of death value of the property. But, property received by gift usually keeps the donor's income tax basis. The income tax basis will make a big difference if the recipient sells the property.

\section{Other Considerations}

Because of the unlimited marital deduction, many married couples simply write a will giving all their property to a surviving spouse. For married couples with estates valued below the exempt amount, this is quite satisfactory from the tax viewpoint, but if the survivor will have more than the exempt amount at death, the final tax bill as the property passes to the children may be greater than necessary. Generally married couples' "all to the spouse" wills are written to ensure the survivor is well cared for. With this as a goal, the use of a trust may provide for substantial tax savings and still meet the objectives. If the first to die put his/her property in a trust for the benefit of the surviving spouse for life with the remainder to the children, estate taxes at the survivor spouse's death would not be increased. Uncertainty of date of death and the resulting property values need to be considered. Fortunately, legal formulas can help alleviate some of these problems. One example is that a person could write a formula so that the exempt amount could go into a "tax-free" trust for the spouse's benefit, and any amount over this could go to a second trust for the spouse's benefit that would qualify for the marital deduction. The objective would be to create a plan where no tax would be paid on the first death, and maybe up to $\$ 7$ million could pass to the final beneficiaries tax free, assuming both parents' estates would be worth $\$ 3.5$ million. Problems with the tax-deferred trust for the surviving spouse are few. In fact, the surviving spouse can be the trustee of the trusts.
Table 4. Estate planning tools for various scenarios

1. Testamentary instruments

- Wills

- Pour-over wills

- Standby trusts

- Account title review/change

- Deeds with retained life estate

2. Lifetime planning

- Declarations of guardian

- Powers of Attorney/Escrow Letter

- Management trust

- Directive to physician

- Healthcare Power of Attorney

3. Planning for children

- Guardian

- Uniform transform to minors

- Minor's trust

- Crummey trust

4. Life insurance

- Tax planning

- Beneficiary designation

- Ownership review

- Life insurance trust

- Policy review

5. Employee benefits

- Tax planning

- Beneficiary designation

6. Charitable

- Gifts

- Foundations

- Community chest

- Lead and/or Remainder trust

7. Value shifting

- Installment sales

- Self-cancelling notes

- Joint purchases

- Sale of remainder interests

- Gifts

- Limited partnerships

- Corporate plans

- Grantor retained income trust

8. Defensive planning

- Homestead

- Partition agreements

- Trusts

- Split interests

- Gifts

- Parents' wills

- Inheritance trust

9. Premarital agreements

- Contracts

- Wills

- Trusts

- Gifts 
But, if other goals are present, such as not allowing anything to go to a "spouse's future spouse," then some hard decisions will need to be made. In this particular case, the taxdeferred trust may not be an appropriate tool with this goal. See Table 4 for a list of other available estate planning tools.

If a goal is to keep the family ranch in the family, a trust is also a desirable vehicle to use. When a person gives property by will, there are no real restrictions that one can put on the property. However, if the ranch was put in a trust with a trustee as legal owner, the trustee could be instructed to hold the ranch for "my living lineal descendants, per stirpes, until the last of my now living lineal descendants dies." That may be a long, long time, and would protect the ranch from going to a non-family member. Whether this would be a wise decision is another matter, given the competing objectives most people have for the care of their loved ones.

Many deem it desirable to keep the family ranch business together and to transfer it as an operating entity to the next generation. Conflicts start when not all of the children want to be employed or involved in the business. Some children may not even want to have an ownership interest in the business, or want to be involved in an investment with siblings. Usually the children who will operate the business want to be free of asking their non-operating siblings for input on business decisions. However, the owner's desire to treat all children "equally or fairly" may override the desire to keep the business together. Therefore, the business may have to be divided so that no one has an economically viable unit. Subsequently, it may have to be sold to one heir or completely dispersed. This problem can be avoided somewhat by separating the ownership of the "land" from the "operation." Most ranches have a substantially greater investment in land than in machinery, equipment, livestock, inventory, and other operating assets. But, the majority of the day-to-day business decisions are with the operation. Separating the ranch business into two legal entities, a landowning entity and a business-operating entity, may be useful. Only the ranching family members would own the operating entity, but all heirs could own a part of the landowning entity. The land could be leased or operated under contract by the operating entity. Also, in the same legal documents provisions could be incorporated so if anyone wanted to sell, others could buy the seller's interest on a prearranged basis, and protections could be written so all heirs would have to get a fair return on their inheritance.
Young ranch families without substantial assets but with children often write a will after quickly deciding to leave all their property to each other, and spend most of their time deciding "who will raise our children if both of us die?" Wills usually name a guardian for the children in that situation. However, providing management for the minor children's property is another matter. The guardian of the children is the person who is in charge of the religious, philosophical, moral, and educational upbringing of the children. If the children are to inherit any assets, it is advisable to consider creating a trust so that a trustee can manage the funds for the children and spend it for their needs without asking a Court for such permission. Also, a trust can be structured so that the property can be held past age eighteen so the child(ren) can gain more maturity in money management before final ownership is transferred. If a couple has more than one child, consideration of a trust for the purpose of "providing for the health, welfare, support, and education of all the children until the youngest living child attains a designated age when the remaining assets shall be distributed to them equally" should be undertaken. What this arrangement does is put a trustee in charge of the family money. Without this provision, all children would take their fractional share, which may be fair if all children were the same age, had the same medical needs, and could benefit from the same type of educational programs. Since most parents spend as needed for their children, the trustee could act as a "substitute parent in charge of money."

\section{Conclusion}

Estate planning is a series of personal decisions. It is a series of trade-offs. Even if a plan is made at one stage in life, it may need revision in a few years. Goals change, people change, assets change, and tax laws change. Thus, estate planning is a dynamic process. Don't put the estate planning documents, like the Will, Trust, Business Plan, or the Power of Attorney, on the top shelf of the cupboard and forget them.

Authors are Professor and Extension Specialist, Texas AEMM University, College Station, TX 77843, USA, law@hayenga. com (Hayenga); and Graduate Fellow, King Ranch Institute for Ranch Management, Texas AE'M University-Kingsville, Kingsville, TX 78363, USA, Conner.Wilson@students.tamuk. edu (Wilson). 